\title{
Palynology of two 4500 year old skua-mounds of the Arctic Skua (Stercorarius parasiticus (L.)) in Svalbard
}

\author{
W. O. VAN DER KNAAP
}

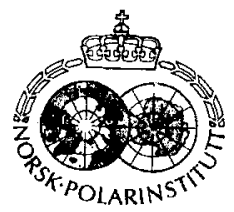

\begin{abstract}
Van der Knaap, W. O. 1988: Palynology of two 4500 year old skua-mounds of the Aretic Skua (Stercorarius parasiticus (L.)) in Svalbard. Polar Research 6, 43-57.

Skua-mounds are peaty hillocks up to $70 \mathrm{~cm}$ high used by Arctic Skuas (Stercorarius parasiticus (L.)) for surveying their breeding territory. Well-developed skua-mounds in Svalbard can be considered as small 'guanogenic bogs', because the peat formation depends on manuring by birds and the water-table in the mound is higher than the surrounding tundra. Peat sections measuring $34 \mathrm{~cm}$ and $40 \mathrm{~cm}$ from two skuamounds from Edgeøya and Spitsbergen were radiocarbon dated and studied for pollen and spores. Peat formation on the two skua-mounds started c. 4500 calendar years ago. Concentration values of longdistance transported pollen were used to detect time gaps in the records. The time gap in the skua-mound from Spitsbergen was found to be considerably greater than in the skua-mound from Edgeøya. Erosion has progressed considerably further on the Edgeøya skua-mound than on the skua-mound from Spitsbergen due to differences in hydrology: the peat of the former mound is dry and unfrozen in summer, whereas in the latter mound it is wet and frozen. Time gaps and erosion are probably associated with phases of decreased manuring by birds. At two levels in the Edgeøya skua-mound there is evidence of a climatic change towards cooler conditions, one being an early major climatic shift and the other a later minor climatic shift. A similar major climatic shift is associated with one level in the skua-mound from Spitsbergen.

W. O. van der Knaap, Arctic Centre, Grote Kruisstraat 2-1, NL-9712 TS Groningen, the Netherlands, or: Laboratory of Palaeobotany and Palynology, Heidelberglaan 2, NL-3584 CS Utrecht, the Netherlands; December 1987 (revised February 1988).
\end{abstract}

There are special problems associated with palaeo-ecological research in high Arctic regions like Svalbard: peat layers are rather scarce, sometimes difficult to detect, and permafrost makes it difficult to penetrate deeper than the $20-30 \mathrm{~cm}$ unfrozen top layer. Another difficulty encountered is the diversity of peat-forming vegetation types: apparently peat layers can form under any vegetation type, provided that the vegetation is closed and that the influx of erosion materials is limited. Peat layers are therefore detected on the basis of landscape characteristics, or they are discovered accidentally.

During field work in 1981 and 1984, the most widespread type of peat in Svalbard was found to be skua-mounds, i.e. watch-hillocks of the Arctic Skua (Stercorarius parasiticus (L.)). Until recently no attention had been given by palynologists to this type of peat. In this paper the development of two skua-mounds is followed by doing palynological studies on radiocarbon dated peat sections, and the results are interpreted in terms of local vegetation succession and possible environmental changes. A preliminary report on the results has been given in Van der Knaap (1988).

\section{Description of sites and environment}

\section{Skua-mounds: general description}

Skua-mounds were seen by the author in Svalbard in nine of the eleven areas visited in 1981 and 1984. All observed skua-mounds are located on coastal plains and are situated between $50 \mathrm{~m}$ and a few $\mathrm{km}$ from the sea. The dimensions are 1$10 \mathrm{~m}$ across and up to $70 \mathrm{~cm}$ high. They are usually conspicuous from a distance owing to the bright green colour of the vegetation which results from strongly manured conditions. Arctic Skuas use them for resting or for surveying their territory; each territory usually contains several skuamounds. Manuring of the skua-mounds due to frequent visits of the birds has often resulted in the formation of peat layers up to $40 \mathrm{~cm}$ thick; plant growth is favoured due to the supply of nutrients, and dead plant material accumulates 
due to the slow decay of organic materials in the high Arctic climate (low temperatures and incorporation of the peat in the permafrost). The general shape of a strongly manured skua-mound in a present-day Arctic Skua territory is domeshaped, with a convex or somewhat flattened top and convex sides that become concave where they merge with the surrounding tundra. In a welldeveloped skua-mound the permafrost level is above the level of the surrounding tundra. Stones, or more often sub-fossil whale-bones, protrude from the sides of most of the skua-mounds; these were probably the watch-posts originally chosen by the Arctic Skuas.

Skua-mounds were observed in the following localities:

Spitsbergen:

- Brøggerhalvøya (see Van Leeuwen \& Van der Knaap 1986), several skua-mounds on Kvadehuksletta, visited 28 July 1981, consisting of peat, tops flattened and hummocky, vegetation dominated by mosses, Arctic Skuas present; one skua-mound near Kongsbreen, little peat formation on top of stones, top rounded, vegetation dominated by Saxifraga caespitosa.

- Hornsund (Fuglebergsletta), visited 2 September 1984, several skua-mounds $800 \mathrm{~m}$ from the coast, in stony tundra; largest skua-mound on top of stones, $50 \mathrm{~cm}$ high, $2.5 \times 3 \mathrm{~m}$ across, top hummocky and eroding, vegetation brown and dominated by mosses, peat layer $23 \mathrm{~cm}$ directly on bedrock, no permafrost.

- Agardhdalen (studied in this paper).

- Agardhpynten, visited 14 August 1984, several skua-mounds; largest skua-mound $80 \mathrm{~m}$ from the coast, $40 \mathrm{~cm}$ high, top rounded, vegetation bright green, dominated by Poa arctica and Cerastium alpinum, peat layer $20 \mathrm{~cm}$, permafrost present.

Edgeøya:

- Meodden (studied in this paper).

- Kapp Lee (Stretehamna), one skua-mound $70 \mathrm{~m}$ from the coast, in moist tundra, $20 \mathrm{~cm}$ high and $2 \times 3 \mathrm{~m}$ across, vegetation dominated by mosses, Alopecurus alpinus cover $15 \%$, Festuca rubra and Saxifraga cernua $10 \%$ each, peat layer $15 \mathrm{~cm}$, no permafrost, Arctic Skuas present in 1986.

- Visdalen, visited 24 August 1984, several skuamounds; largest skua-mound $300 \mathrm{~m}$ from the coast, in dry tundra, $45 \mathrm{~cm}$ high and $1.5 \times 3.5 \mathrm{~m}$ across, whale-bone at the base, top rounded, vegetation bright green and dominated by mosses (cover 50\%), Alopecurus alpinus 25\%, Festuca rubra $25 \%$, peat layer $42 \mathrm{~cm}$, permafrost at base.

- Diskobukta (Raddesletta), visited 25 August 1984, several skua-mounds; largest skua-mound $1 \mathrm{~km}$ from the coast, in wet tundra, on top of two $6 \mathrm{~m}$ long whale-jaws, $70 \mathrm{~cm}$ high and $10 \times 15 \mathrm{~m}$ across, top somewhat hummocky, vegetation dominated by mosses, vascular plant cover $40 \%$ (Salix polaris $20 \%$, Poa arctica $15 \%$, Alopecurus alpinus 5\%), peat layer $25 \mathrm{~cm}$ thick. - Russebukta, several large skua-mounds c. $1 \mathrm{~km}$ from the coast; no description available.

The type of peat on skua-mounds needs careful classification. Salvigsen (1977) has described icecored palsa-like forms from Nordaustlandet (Svalbard) similar in size and shape to large skuamounds and assumed that these forms came into existence by frost action. It is evident, however, that all mounds described above (with the possible exception of those at Russebukta) are skuamounds, since they all have one or more of the following characteristics: presence of Arctic Skuas, bright green and therefore strongly manured vegetation, stones or whale-bones at the base, absence of permafrost, or presence of permafrost but absence of a core of ice. Gore (1983) discusses various mire classifications. In his opinion the most satisfactory definition for fens and bogs is that of Moore \& Bellamy (1974, p. 80): 'fens are mires influenced by water derived predominantly from outside their immediate limits; bogs are influenced solely by water that falls directly on to them as rain or snow'. This definition concerns only the hydrology and focuses on the origin of the water influencing the peat-forming vegetation. Skua-mounds having a permafrost level above the surrounding tundra are therefore 'bogs'. The definition of Moore \& Bellamy neither refers to the size nor to the nutrient level, so fens and bogs can be rich or poor in nutrients. Bogs with a high nutrient level are uncommon, but well-known examples are the Icelandic bogs, where the deposition of dry volcanic ash causes a high nutrient level. The skuamounds are another example, since peat growth depends on the deposition of bird droppings; the peat is therefore referred to here as 'guanogenic'. In conclusion, fully developed skua-mounds of the Arctic Skua in Svalbard (having a permafrost level above the surrounding tundra and peat growth depending on manuring by birds) can be termed small 'guanogenic bogs'. 


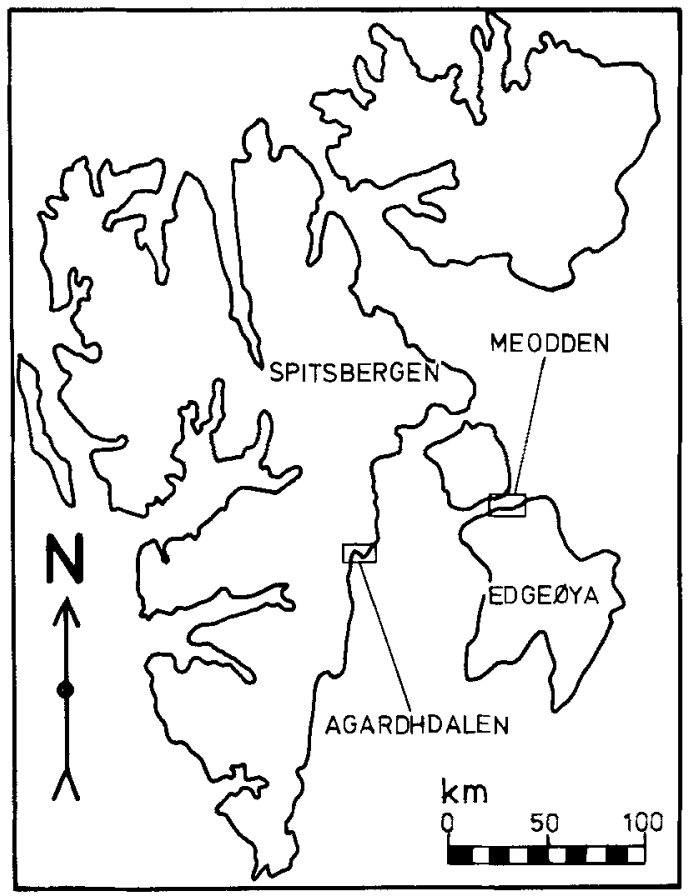

Fig. 1. Map of Svalbard, showing the sites Meodden and Agardhdalen.

\section{The Meodden and Agardhdalen skua-mounds}

The locations of the studied skua-mounds are shown in Figs. 1, 2 and 3. They are c. $75 \mathrm{~km}$ apart. No stones or whale-bones were observed at the base of these mounds. The Meodden skua-mound (Fig. 4) is located on a coastal terrace along the sound Freemansundet on the north coast of the island of Edgeøya, Svalbard, near the promontory called Meodden $\left(78^{\circ} 12^{\prime} 30^{\prime \prime} \mathrm{N}, 21^{\circ} 52^{\prime} \mathrm{E}\right)$. The altitude is c. $15 \mathrm{~m}$ a.s.l., the sea-shore is c. $300 \mathrm{~m}$ to the north and the foot of the bare hill slopes is $c$. $50 \mathrm{~m}$ to the south. The site was visited on 12 August 1984; no Arctic Skuas were observed. The skua-mound measures c. $3 \times 5 \mathrm{~m}$ and is $40 \mathrm{~cm}$ high. It is built up of many small hummocks with a surface of c. $20 \times 40 \mathrm{~cm}$. Hummocks are highest in the central $2 \mathrm{~m}^{2}$ and decrease gradually in height towards the periphery. The peat section was taken from the highest hummock in the centre of the skua-mound. The vegetation on this central hummock is bright green in colour, whereas on the rest of the skua-mound it is brown and grey. The entire skua-mound is densely overgrown with grass. The vegetation of the central hummock is as follows (nomenclature follows Rønning (1979); $\mathrm{f}=$ with flowers (sometimes viviparous), $\mathrm{s}=$ sterile): Moss cover $10 \%$. Vascular plant cover $100 \%$. Poa arctica $60 \%$ f (viviparous), Alopecurus alpinus $30 \%$ f, Stellaria crassipes $15 \%$ s, Cochlearia officinalis 5\% s, Saxifraga cernua $1 \% \mathrm{f}$. Additional species on the rest of the skua-mound: Cerastium alpinum $\mathbf{f}$, Stellaria crassipes f (single flowering specimens), Ranunculus sulphureus $\mathrm{f}$, Salix polaris $\mathrm{f}$, Luzula arctica $\mathrm{f}$. Additional species in the tundra within a few metres of the skuamound (all f): Sagina intermedia, Cardamine bellidifolia, Draba spp., Phippsia algida, Oxyria digyna, Polygonum viviparum, Saxifraga caespitosa, S. nivalis, S. hirculus, Luzula confusa, Papaver dahlianum. The skua-mound is surrounded by open, dry tundra with the following vegetation: Moss cover 50\%. Lichen cover $10 \%$. Vascular plant cover $15 \%$. Salix polaris $8 \%$,

Fig. 2. Map of the northern coast of Edgeøya, showing the site Meodden.

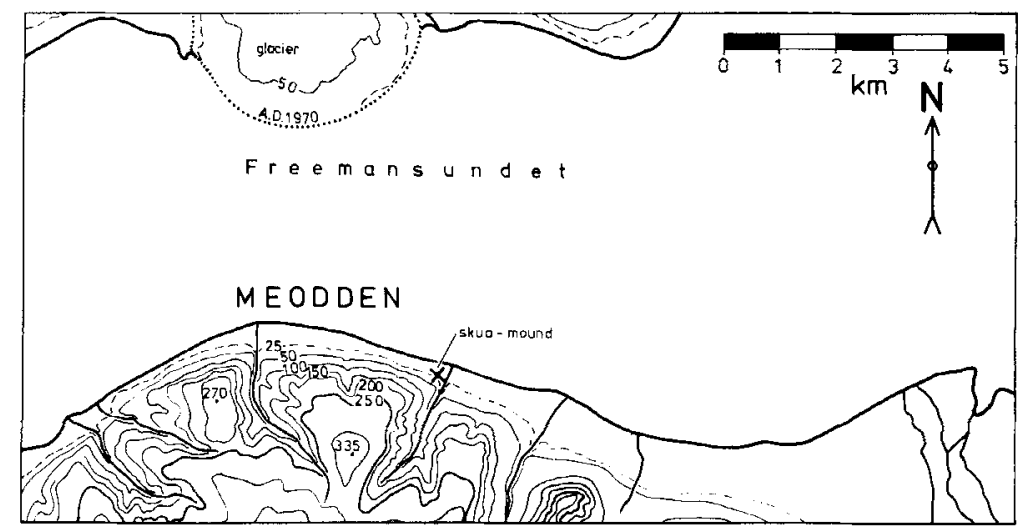




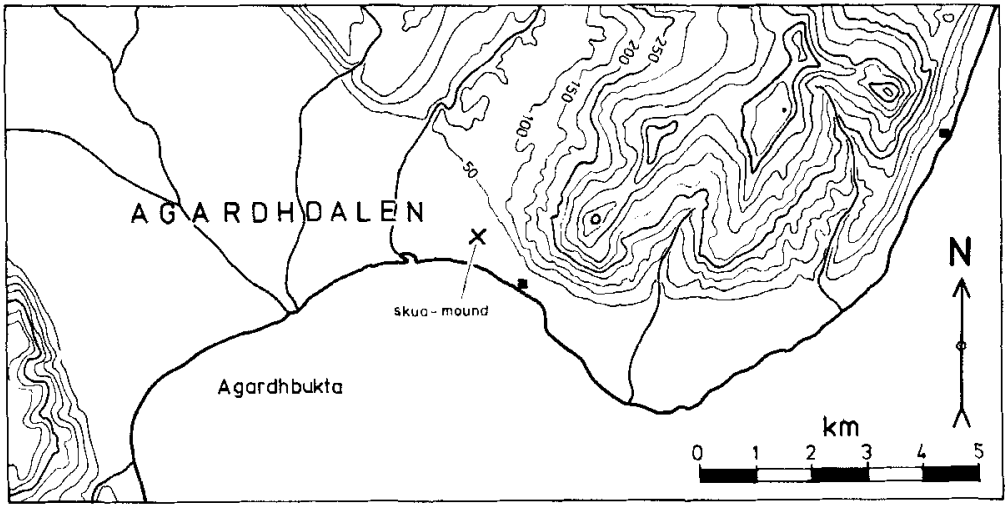

Fig. 3. Map of part of the east coast of Spitsbergen, showing the site Agardhdalen.
$<1 \%$ : Saxifraga caespitosa f, S. hirculus f, Luzula arctica $\mathrm{f}$, Cerastium regelii $\mathrm{s}$, Alopecurus alpinus s, Poa arctica s, Oxyria digyna s.

The Agardhdalen skua-mound (Fig. 5) is located on a coastal terrace on the eastern coast of the main island Spitsbergen, along the bay of Agardhbukta (part of the sound Storfjorden), in the eastern part of Agardhdalen and west of a hut $\left(78^{\circ} 3^{\prime} 20^{\prime \prime} \mathrm{N}, 18^{\circ} 37^{\prime} \mathrm{E}\right)$. The altitude is c. $10 \mathrm{~m}$ a.s.l., the sea shore is c. $500 \mathrm{~m}$ to the south, the foot of

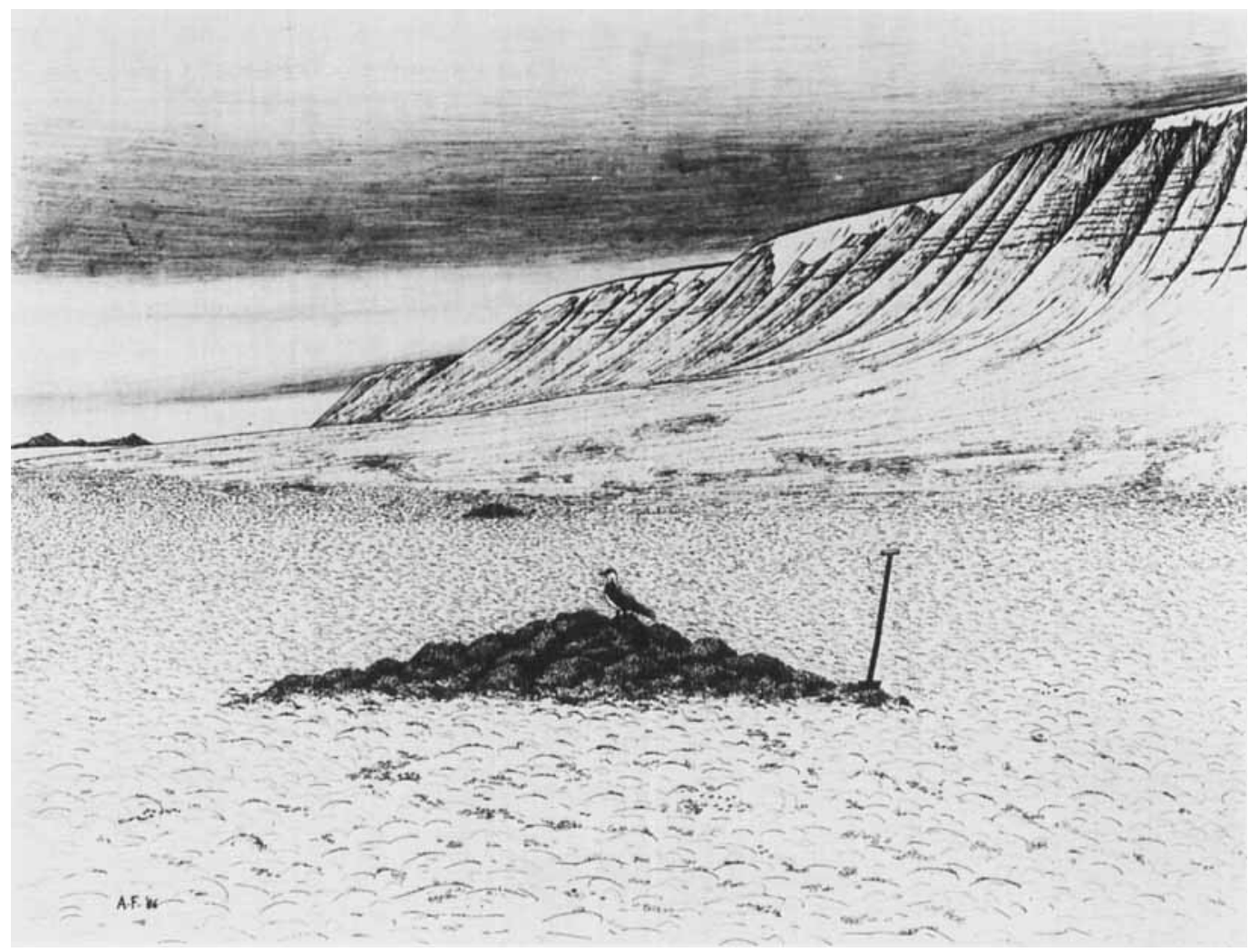

Fig. 4. Meodden: the investigated skua-mound. A second skua-mound is visible in the background. The Arctic Skua was not actually present but has been added drawn to scale. (Redrawn by Aljos Farjon from a photograph by the author.) 


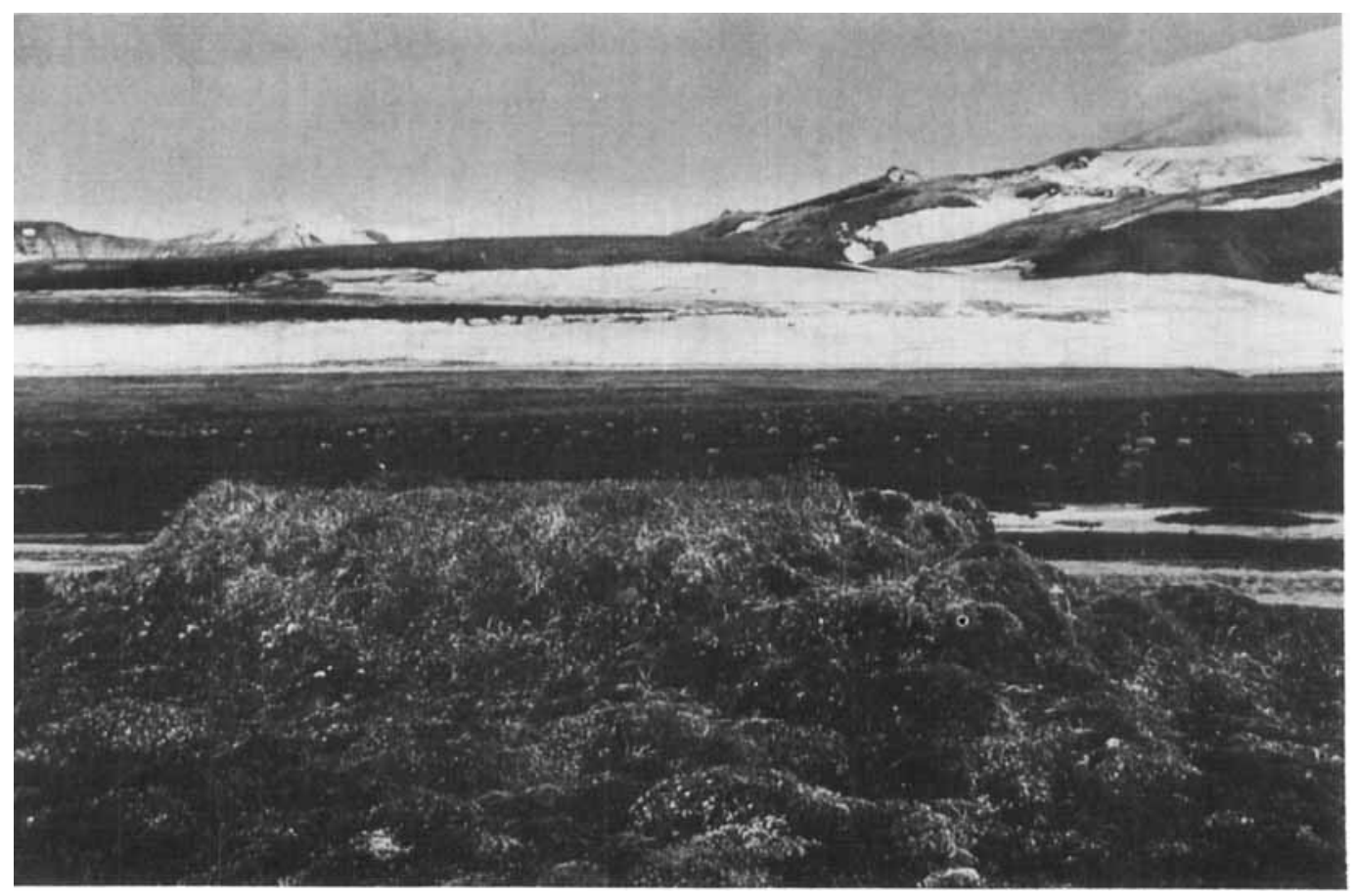

Fig. 5. Agardhdalen: the investigated skua-mound. (Photograph by the author.)

the hills is c. $500 \mathrm{~m}$ to the north. The site was visited on 13 August 1984; no Arctic Skuas were observed. The skua-mound measures c. $2 \times 3 \mathrm{~m}$ and is $50 \mathrm{~cm}$ high. The top is flattened and one $\mathrm{m}$ across, the hummocky sides are steepest near the top and level out lower down. The vegetation on the top is as follows: Moss cover 95\%. Lichen cover $2 \%$. Vascular plant cover $10 \%$. Stellaria crassipes $9 \% \mathrm{f}$, Cochlearia officinalis $<1 \%$ s, Ranunculus sulphureus $<1 \%$ s, Poa arctica $<1 \%$ $s$. The vegetation of the entire skua-mound including the top is as follows: Moss cover $90 \%$. Lichen cover $2 \%$. Vascular plant cover $8 \%$. Stellaria crassipes $4 \%$ f, Poa arctica $3 \%$ f, Salix polaris $1 \%$, Cochlearia officinalis $<1 \%$ f, Ranunculus sulphureus $<1 \% \mathrm{f}$, Alopecurus alpinus $<1 \% \mathrm{f}$, Saxifraga cernua $<1 \% \mathrm{f}$. The skua-nound is surrounded by wet tundra with locally abundant moss growth and stagnant pools. The vegetation of the tundra up to ten $\mathrm{m}$ from the skua-mound is as follows: Moss cover $50 \%$. Lichen cover $<1 \%$. Vascular plant cover $7 \%$. Dupontia sp. $2 \%$ f, Salix polaris $2 \%$, Luzula arctica $2 \%$ f, Saxifraga rivularis $1 \%$ f, Sagina intermedia $<1 \%$ f, Cochlearia officinalis $<1 \%$ f, Draba sp. $<1 \%$ f, Polygonum viviparum $<1 \% \mathrm{f}$, Ranunculus sulphureus
$<1 \%$ f, Saxifraga cernua $<1 \%$ f, Saxifraga oppositifolia $<1 \% \mathrm{f}, S$. nivalis $<1 \%$ f, $S$. foliolosa $<1 \%$ s.

\section{Methods}

\section{Sampling in the field}

Meodden. - A $20 \mathrm{~cm}$ wide slit was dug in the side of the skua-mound adjacent to the sampling site. A section measuring c. $15 \times 20 \times 40 \mathrm{~cm}$ was extracted from the highest hummock in the centre of the skua-mound and packed in a plastic box. A sample from the base of the section was packed separately for radiocarbon-dating. No permafrost was encountered. The shape and the vegetation of the skua-mound were carefully restored with the dug-out material, supplemented with material from the tundra.

Agardhdalen. - The centre of the skua-mound appeared to be frozen and could not be penetrated. C. $25 \mathrm{~cm}$ of the peat was unfrozen on the sides, but only $10 \mathrm{~cm}$ was unfrozen in the central part of the flattened top. A section was therefore collected from the steepest side (incli- 


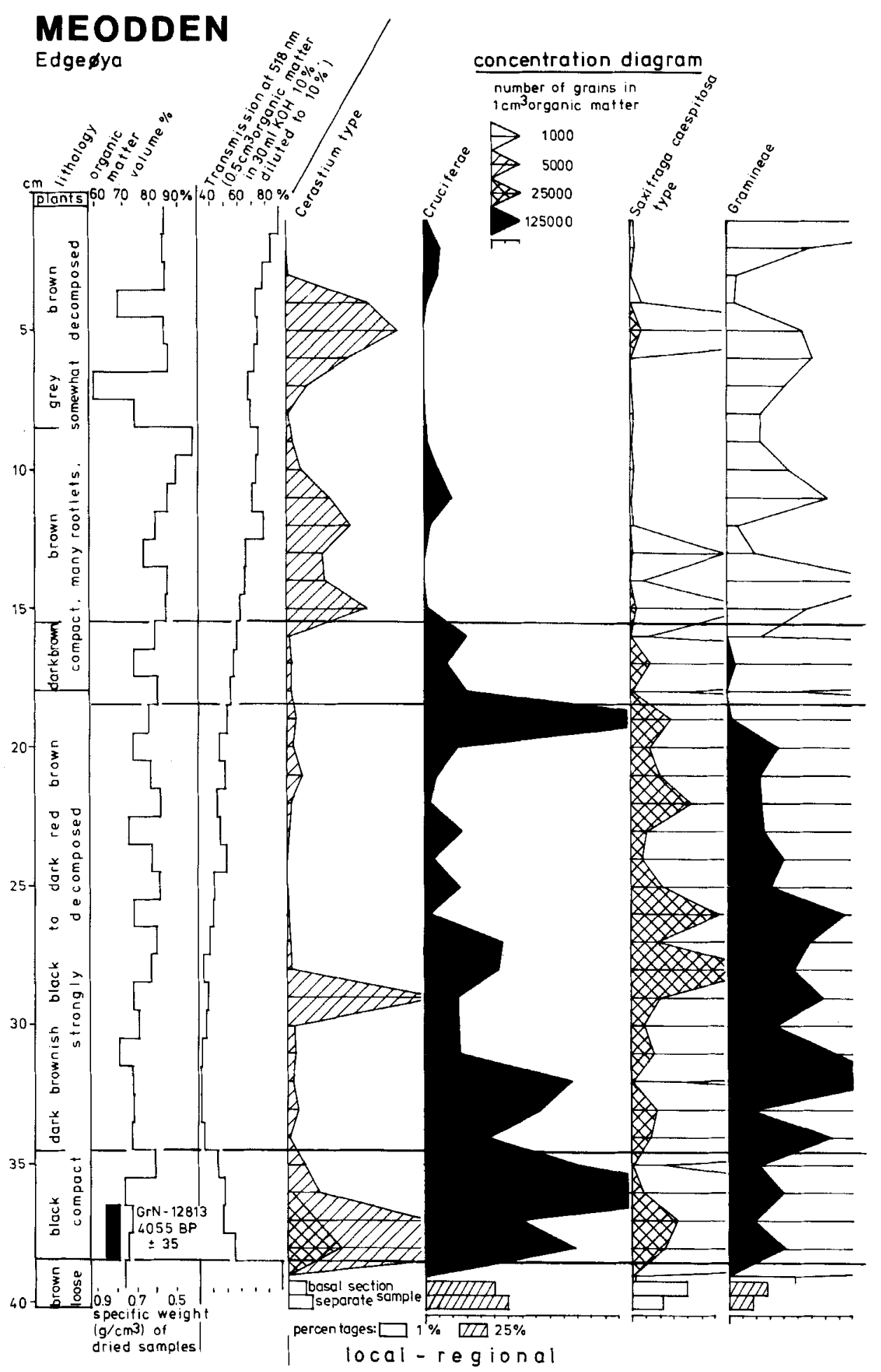

Fig. 6. Concentration diagram of pollen and spores of the Meodden section. 


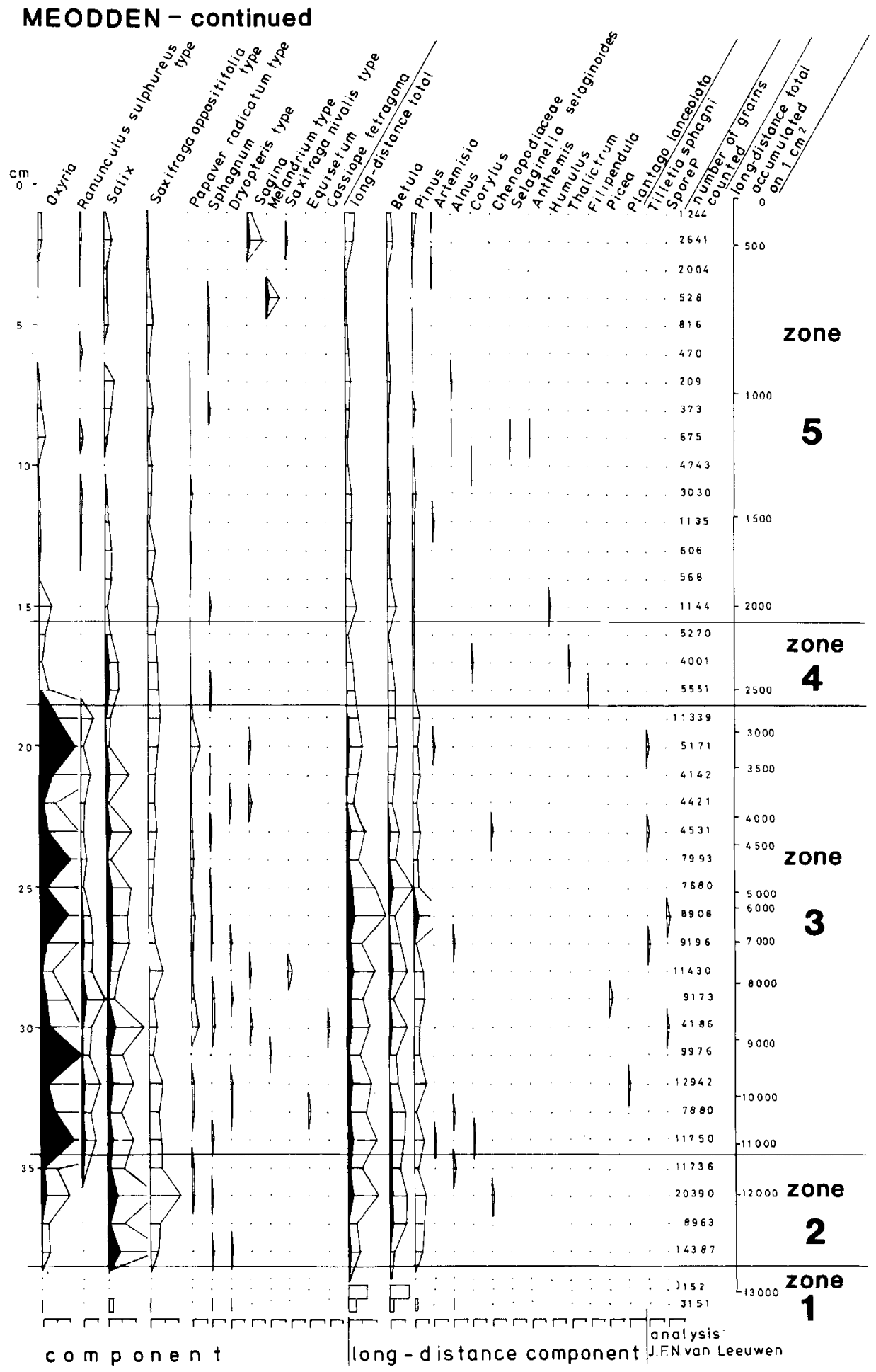


nation c. $60^{\circ}$ ) downwards from the edge of the flattened top, parallel to the side. The section measures c. $15 \times 20 \times 47 \mathrm{~cm}$ and was packed in a plastic box. The shape and the vegetation of the skua-mound were restored as far as possible.

\section{Laboratory methods}

The sections were sampled contiguously at $1 \mathrm{~cm}$ intervals for the analysis of pollen and spores. Sample volume was measured by pushing the material with a spatula into a small sampler with a volume of $0.26 \mathrm{~cm}^{3}$. Two of the three basal samples of the Agardhdalen section measure $4 \times 0.26 \mathrm{~cm}^{3}(32 \mathrm{~cm}, 33 \mathrm{~cm})$, the third $5 \times 0.26 \mathrm{~cm}^{3}(34 \mathrm{~cm})$; the other samples of both sections measure $3 \times 0.26 \mathrm{~cm}^{3}$. At a later date, a large additional sample of unknown volume was taken from the Meodden section at the same depth as the basal sample because the basal sample appeared to be poor in pollen. Stones larger than a few $\mathrm{mm}$ were discarded and not included in the samples. Dry weight was measured. The samples of the Meodden section were prepared for transmission measurement as follows: addition of $30 \mathrm{ml} \mathrm{KOH} 10 \%$ at roomtemperature, thorough mixing with a spatula, remixing after 10,20 and 30 minutes, centrifuging, dilution of the decanted liquid with water to $10 \%$, transmission measurement of the diluted solution with a Vitatron colorimeter through a $518 \mathrm{~nm}$ filter.

The samples of the two sections were prepared for pollen analysis following in general Fægri \& Iversen (1975). Pollen and spore concentrations were determined by the addition of tablets containing a known number of spores of Lycopodium clavatum (Stockmarr 1971). The methods can be summarized thus: (1) addition of a Lycopodium tablet (to the Meodden samples after the transmission measurement) and gentle heating for 5 minutes in $\mathrm{HCl} 30 \%$, (2) heating of the Agardhdalen samples for 5 minutes in $\mathrm{KOH} 10 \%$, (3) sieving over a 0.12 mesh screen, (4) removal of part of the sand and bigger organic particles by careful decanting, (5) gentle heating at $60^{\circ} \mathrm{C}$ in $\mathrm{H}_{2} \mathrm{O}_{2} 10 \%$ for 10 minutes, a treatment which removes part of the organic material but leaves the pollen grains intact, (6) cold overnight treatment with HF $30 \%$, (7) acetolysis.

The peat of both sections contains many small shale-stones up to a few $\mathrm{cm}$ in length. Specific weights of the shale-stone and the organic frac- tions were determined as follows: (1) $2 \mathrm{~cm}^{3}$ of peat containing shale-stones was sampled, dry weight and loss-on-ignition were determined, and the volume of the pure shale-stone residue was measured. (2) Dry weight and loss-on-ignition of a shale-stone sample extracted from the peat were determined. (3) The results of (2) were used to calculate the weight of the shale-stone fraction in (1) before ignition. Specific weights could now be calculated: $1.73 \mathrm{~g} / \mathrm{cm}^{3}$ of the dried shale-stones, $0.34 \mathrm{~g} / \mathrm{cm}^{3}$ of the dried organic material. The volume of the organic fraction in the pollen samples was calculated with the help of the specific-weight values (Figs. 6 and 7, extreme left).

Two radiocarbon dates were provided by Prof. Dr. W. G. Mook, Isotope Physics Laboratory, Groningen, the Netherlands.

\section{Identification and nomenclature of pollen and spores}

All pollen grains and spores of vascular plants and Sphagnum were identified and counted. The paper of Verbeek-Reuvers (1977) was used for the identification of Saxifragaceae pollen, but two types have been renamed after species occurring in Svalbard (Rønning 1979). Saxifraga granulata type is renamed Saxifraga caespitosa type, which includes $S$. cernua, $S$. rivularis and $S$. hyperborea. Saxifraga stellaris type is renamed Saxifraga nivalis type, which includes $S$. tenuis, $S$. hieraciifolia and the viviparous $S$. foliolosa (usually without fertile flowers in Svalbard). Saxifraga oppositifolia type includes $S$. aizoides. Ranunculus sulphureus type includes $R$. nivalis and $R$. pedatifidus. Ranunculus hyperboreus type includes $R$. pygmaeus, $R$. lapponicus, $R$. glacialis, $R$. pallasii and $R$. spitsbergensis. Cerastium type includes Stellaria spp. Silene type includes Arenaria spp., Minuartia rubella and $M$. biftora. Melandrium type includes Minuartia stricta. A number of different spore types were counted: 'Spore P' and Tilletia sphagni. For a description of Spore P see Van der Knaap (1987).

\section{Presentation}

\section{Pollen and spore diagrams}

The quantities of pollen and spores presented in concentration diagrams (Figs. 6 and 7) are 
AGARDHDALEN

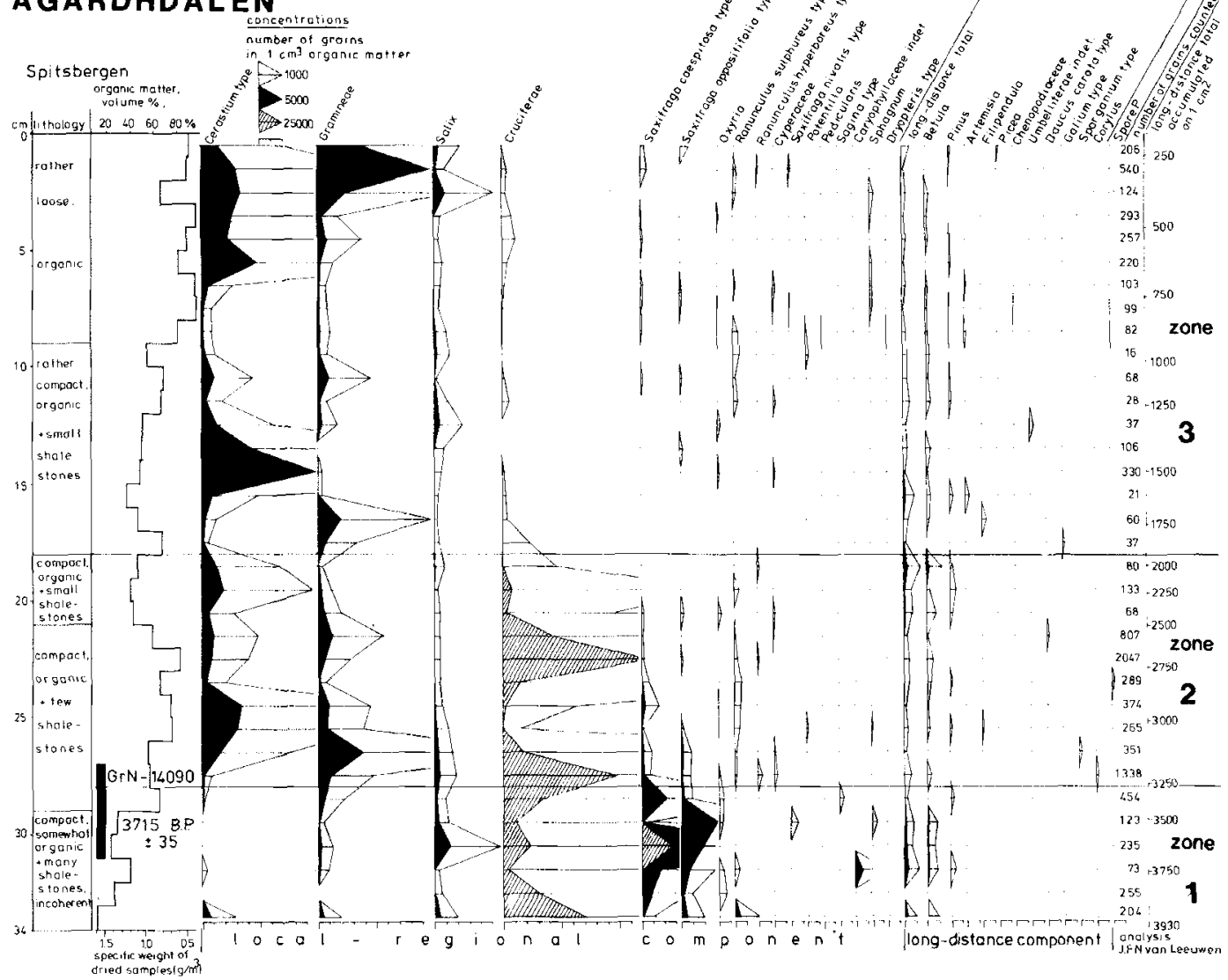

Fig. 7. Concentration diagram of pollen and spores of the Agardhdalen section.

expressed as the number of grains in $1 \mathrm{~cm}^{3}$ organic matter. On the far right cumulative values are given for the total amount of long-distance pollen and spores (a method introduced in Van der Knaap 1987). The cumulative long-distance value at a certain level is defined here as the number of long-distance grains that have accumulated in the sediment on a $1 \mathrm{~cm}^{2}$ column above that level. These values are calculated from the total longdistance concentrations and the volume percentages of organic matter. At the base of Fig. 6 two spectra are drawn as histograms (percentages of total pollen); the upper spectrum represents the basal section sample (also drawn as the basal spectrum of the diagram), the lower represents the additional sample. Zones are established in both diagrams for ease of reference. The criterion for zonation is that a pollen assemblage is more homogeneous within a zone than between zones. In the diagrams the pollen and spore types are grouped into two categories, as in earlier work (Van der Knaap 1985):

- Local-regional component: pollen and spores that are presumed to be derived from plants growing in Svalbard.

- Long-distance component: pollen and spores originating from areas outside Svalbard.

Summary percentage diagrams of the two skuamounds are presented in Van der Knaap (1988). These are not discussed here, as they do not provide additional results.

\section{Prequaternary pollen and spores}

Several hundred prequaternary pollen grains and spores were found in the pollen samples. These were not counted accurately and are not shown in the diagrams, but Dr. W. A. Brugman, Laboratory of Palaeobotany and Palynology, Utrecht, the Netherlands was kind enough to identify some 
of them: Uvaesporites sp., Convolutispora sp., Camarozonosporites rudis, Triadaspora plicata, Concavisporites sp. and Converrucosporites sp. These spores were undoubtedly blown in with the shale-stone fraction.

\section{Lithology}

The lithology of the sections is partly described in the diagrams (Figs. 6 and 7, extreme left). Additional information is given here.

Meodden section. - Zone 1 consists of gravel, the other zones of peaty materials. The stratification is very clear and horizontal throughout and does not follow the contours of the hummocks. The layers differ in colour, number of stones and degree of preservation of plant material. Vertical and diagonal frost cracks present at irregular intervals of $5-10 \mathrm{~cm}$ do not interfere with the horizontal stratification. Pollen samples were not collected within frost crack areas. The material from zones 3 to 5 is dry and seems to be waterpermeable, that of zones 1 and 2 is rather moist. In zones 4 and 5 abundant grass-leaves and rhizomes could be recognized, in zone 3 these are sparse and in zones 2 and 1 they are absent.

Agardhdalen section. - The basal part of zone 1 (29-34 cm) consists of gravel mixed with organic material, the overlying layers consist of peaty materials. The stratification is very clear and horizontal. The layers differ in colour, in the number of stones they contain and in degree of preservation of plant material. The layers end abruptly at the sides and do not follow the contours of the skua-mound. The centre of the skuamound is water-saturated and frozen. The amount of rhizomes of grass and rootlets decreases gradually from the top downwards to a depth of $25 \mathrm{~cm}$; rhizomes are absent between 25 and $34 \mathrm{~cm}$.

\section{Comments on plant ecology}

The ecology of the plant species, in particular the relation between the species and manuring by birds, serves as a basis for the interpretation of the pollen diagrams. Relevant information on the ecology of plant species represented by the dominant pollen types is summarized here. This information is based on field observations of the author and on Eurola \& Hakala (1977).

- Cerastium type: Cerastium arcticum grows abundantly on moderately manured sites, Stellaria crassipes can also grow on such sites, but other species are unlikely to grow on manured sites.

- Cruciferae: only Cochlearia officinalis on strongly manured sites has a high pollen production. Other Cruciferous species are not often encountered on manured sites.

- Gramineae: grass plants flower abundantly only on sites that are manured to varying degrees; most common species on these sites are Poa spp. (often viviparous forms) and Alopecurus alpinus.

- Saxifraga caespitosa type: all species become abundant under fairly strongly manured conditions.

- Salix: S. polaris is very common, the other species are rare. Salix species tolerate moderate manuring, but not heavy manuring.

- Saxifraga oppositifolia type: the very common $S$. oppositifolia and the rare $S$. aizoides are seldom found on manured sites.

- Ranunculus sulphureus type: Ranunculus sulphureus has a preference for manured sites; other species are not likely to grow on or near skua-mounds.

\section{Results}

\section{Lithology}

Meodden. - The lithology of zone 1 at the base of the Meodden section is very different from that of the overlying zones in that the material is not peaty. The material probably represents the old soil surface prior to the formation of the skuamound.

The higher transmission values in zone 2 compared to zone 3 are probably due to a difference in moisture: the peat is nearly water-saturated in zone 2 but drier in zone 3 , and water-saturation prevents the inwash of humic acids and retards peat decomposition.

The lithological horizon at $18 \mathrm{~cm}$ between zones 3 and 4 is very marked, particularly by the degree of decomposition. However, this horizon is not reflected in the transmission values, which are a relative measure of concentrations of humic acids formed during decomposition. Therefore the original humic acid gradient has probably been smoothed by the outwash of humic acids from the 
upper layers, possibly combined with inwash into deeper layers. This is in agreement with the observation that during summer the peat of zones 3-5 is dry, water-permeable and unfrozen. A possible interpretation of the abrupt transition at $18 \mathrm{~cm}$ is that it reflects an abrupt cooling of the climate, resulting in a retardation of the decomposition of peat layers formed later.

The curve for volume-\% of organic matter (Fig. 6 , left) shows that the shale-stone fraction decreases from the base to a depth of $8.5 \mathrm{~cm}$ (in the middle of zone 5). This decrease may be related to the progressive elcvation and enlargement of the skua-mound. Possible explanations for the sharp increase of the shale-stone fraction above $8.5 \mathrm{~cm}$ are:

- Increased shale-stone deposition due to a climatic change unfavourable for plant growth (cooler and/or drier); this resulted in partial destruction and opening up of the surrounding tundra vegetation and rendered the tundra more susceptible to wind erosion.

- Decreased rate of peat growth due to decreased manuring by skuas. Diminished use of breeding territory by Arctic Skuas is most likely to be associated with a deterioration of the conditions for breeding and/or foraging. A connection with climatic change seems likely. This idea is supported by the observations made by De Korte (1972) in the second half of July 1969 on Edgeøya; he noted that the breeding frequency of Arctic Skuas was lower along coasts where sea-ice was present until late spring. In 1969 Meodden was critically located for the breeding of Arctic Skuas: on the western and northern coast up to Meodden sea-ice was broken and breeding Arctic Skuas were observed. In contrast, on the northern coast, east of Meodden, and on the eastern coast, the sea was covered with solid ice and no breeding Arctic Skuas were observed.

Indications of peat formation on the Meodden skua-mound having ceased and of degradation of formed peat layers having taken place are the hummocky morphology, the presence of frost cracks, the horizontal stratification that does not follow the contours of the hummocky surface, the dryness of the peat, the absence of permafrost and the brown and grey colours of the vegetation (with the exception of the central hummock) which point to a low nutrient level and absence of intense manuring by birds. During the time of peat formation the skua-mound was probably dome-shaped with permafrost in the central part. The cause of the cessation of peat growth could be diminished manuring associated with a diminished use of the skua-mound by Arctic Skuas. It seems probable that when erosion started after the cessation of peat growth, the formation of frost cracks enhanced drainage and caused a lowering of the permafrost level, resulting in the present-day dry skua-mound devoid of permafrost.

Agardhdalen. - High specific-weight values were found in the basal gravel layers $(29-34 \mathrm{~cm})$ of the Agardhdalen section. These layers may represent the soil surface at the time when formation of the skua-mound started. Specific-weight values for the peat layers between 9 and $22 \mathrm{~cm}$ were distinctly higher than those for adjacent layers, pointing to a period with either decreased rate of peat growth or increased shale-stone influx, or both.

The morphology of the skua-mound, flattened top, concave sides and horizontal stratigraphy that ends abruptly at the sides, indicates that peat growth has ceased and that some erosion has taken place at the sides.

Comparison of the two sites. - Although it is assumed that peat growth has ceased on the two skua-mounds, the mound surfaces are completely covered by recent vegetation. The explanation for this apparent contradiction is that the biomass production today is equal to or outweighed by decomposition, resulting in stagnation of peat growth or erosion. The deposition gap at the top of each section is therefore situated at the base of the vegetation layer.

Erosion has progressed much further on the Meodden skua-mound, which is situated on a dry tundra, than on the Agardhdalen skua-mound, which is situated on a wet tundra. The reason is probably that on dry tundra stagnation of peat growth triggers within a shorter time the following sequence of events: formation of frost cracks, dehydration, lowering of the permafrost level, erosion.

\section{Pollen stratigraphy and past vegetation}

The large fluctuations in the concentration values for the dominant pollen types (Figs. 6 and 7) indicate that the pollen curves have not been smoothed during downwash of pollen. Dips and 
peaks in the curves of various pollen types are not correlated; this indicates that the fluctuations are not associated with fluctuations in the rate of peat accumulation.

Two different types of general trends can be observed in the curves of the dominant pollen types:

(1) The curves of Salix, Saxifraga oppositifolia type and Papaver radicatum type in Meodden show a trend similar to that of the total longdistance curve. This indicates that the abundance of the species producing these pollen types has not fluctuated greatly in the recorded period.

(2) The curves of (both diagrams:) Cerastium type, Cruciferae, Saxifraga caespitosa type, Gramineae, (Meodden:) Oxyria, Ranunculus sulphureus type, (Agardhdalen:) Saxifraga oppositifolia type and Salix show trends basically different from those of the total long-distance curves. This suggests fluctuations in the abundance or the pollen production of the relevant species. Changes in the dominance of vascular plant species point to fluctuating intensities of manuring by birds. Periods of very low manuring may have given rise to time gaps in the record due to stagnation of peat growth. However, these gaps have not been traced.

The diagrams are interpreted below in terms of past vegetation.

Meodden. - It is apparent from the recent vegetation dominated by grass, from the lithology (abundant grass-leaves in zones 4 and 5) and from the Gramineae pollen concentrations (high in zones 2 and 3 ) that the skua-mound has been covered continuously by grass. One can explain the difference in the Gramineae pollen concentrations for zones $2 / 3$ and zones $4 / 5$ by assuming that the dominant grass plants during zones 2 and 3 were abundantly flowering and non-viviparous (and therefore producing pollen abundantly), whereas during zones 4 and 5 they were predominantly viviparous (and therefore did not produce pollen), just like the dominant grass Poa arctica on the skua-mound today. Five pollen zones are distinguished:

Zone 1. - Concentrations of all pollen types are low, indicating scarcity of vascular plants (including grass) and a low nutrient level.

Zones 2 and 3. - High concentrations of many types, pointing to high local abundance of plants and a high nutrient level. Ranunculus sulphureus probably immigrated onto the skua-mound in zone 3. An increased abundance of $O x y$ ria digyna and a decreased abundance and/or flowering of Cerastium sp. and/or Stellaria cf. crassipes are suggested at the transition from zones 2 to 3 .

Zone 4. - Transitional between zones 3 and 5 and characterized by a strong decrease in pollen concentrations, either gradual, or at the top or base. Concentrations of the dominant pollen types correspond either to those in zone 3 , or to those in zone 5, or are intermediate. It is concluded that the abundance and/or flowering of the plants decreased, either due to decreased manuring by birds or to a climatic change unfavourable for plant growth, or both.

Zone 5. - In contrast to the general decrease of pollen concentrations, values of Cerastium type are much higher than in zones 3 and 4 . This points to the local abundance of Stellaria crassipes and/ or Cerastium alpinum, which are the two species producing this pollen type in the present vegetation. Periods of stagnation in peat growth due to very low manuring seem possible in this zone. The upper sample has pollen concentrations that fit well into zone 5 , in spite of the deposition gap inferred at the base of the vegetation layer. This leads us to the conclusion that the entire zone represents a vegetation similar to the present-day vegetation on the skua-mound.

Agardhdalen. - The peat layers between 9 and $22 \mathrm{~cm}$, distinct from adjacent layers by their relatively high specific-weight values, are not evident in the pollen stratigraphy, and no conclusions have been drawn. Three pollen zones are distinguished:

Zone 1. - The high concentrations of Cruciferae and Saxifraga caespitosa type point to the local abundance of plants typical for a manured soil. On the other hand, the high concentrations of Saxifraga oppositifolia type point to the presence of species typical for unmanured conditions. One can explain this apparent contradiction by assuming that this zone represents tundra soil poor in nutrients adjacent to a young manured skua-mound still smaller than today. This is in agreement with the situation of the section at the side of the skua-mound and with the lithology pointing to a soil and not to peat as in zones 2 and 3. This implies that the beginning of the skuamound is somewhat earlier than the radiocarbon date for the base of the section. 
Zone 2. - The high concentrations of Cerastium type, Gramineae and Cruciferae indicate local abundance of the plants, resulting from manuring on the growing skua-mound.

Zone 3. - The low abundance or flowering of Cruciferous plants indicated by the low pollen concentrations compared to zone 2 is possibly associated with decreased manuring by birds and associated cooling of the climate (De Korte 1972). Periods of stagnation in peat growth due to very low manuring seem probable in this zone. For the same reasons as those given concerning the Meodden skua-mound the vegetation represented by the upper zone is probably similar to the present-day vegetation on the skua-mound.

Comparison of the two sites. - The aspect of the present-day vegetation on the two skua-mounds differs: in Meodden, grass is dominant, in Agardhdalen, mosses are dominant. It is apparent from the pollen stratigraphy that this difference existed during the entire period of peat formation. In spite of this difference, there are several important points of similarity:

- On both skua-mounds the vegetation has been peat-forming.

- The diagrams suggest fluctuating abundance of the dominant vascular plant species, which is interpreted in terms of fluctuating intensities of manuring.

- The pollen stratigraphy of both skua-mounds reflects a transition from a strongly to a moderately manured vegetation at a level about half-way up the sections.

- In addition to the presumed time gap in the record at the top of the sections, there were probably more time gaps in the upper zone of both skua-mounds.

\section{Chronology}

The basal levels of the two sections have been radiocarbon dated. The abundance of rootlets in higher layers prevented radiocarbon dating of additional levels. In the following, radiocarbon dates are converted into calendar years; calibrated dates are shown by the prefix 'cal'.

The calibration of the radiocarbon date in the Meodden section (4055 B.P. \pm 35 ; GrN-12813) yields two possible results: cal 2505-2655 B.C. or cal 2825-2855 B.C. (Pearson et al. 1986). However, according to Mook et al. (1979) the ${ }^{14} \mathrm{C}$ correction curve can be smoothed for 'long-lived' samples covering a large span of time (c. 100 years or more), as is usual with peat-samples and most probably with this sample, too. The calibration date after visual smoothing is cal $2500-2650 \mathrm{~B}$.C.

The calibrated radiocarbon date in the Agardhdalen section (3715 B.P. $\pm 35 ;$ GrN14090) is cal 2040-2200 B.C. (Stuiver \& Becker 1986).

Comparison of the two sites. - The radiocarbon date of the Agardhdalen section is cal $300-600$ years less than that of the Meodden section. It was pointed out above that peat formation on the Agardhdalen skua-mound must have begun somewhat earlier than the radiocarbon date, whereas the radiocarbon date from Meodden probably reflects the beginning of the skuamound. The difference between the times when the two skua-mounds began therefore must be less than $300-600$ years. The mounds date back to about the same period and they are c. 4500 calendar years old. Shoreline displacements in Svalbard during the last 10,000 years are fairly well known (e.g. for eastern Svalbard, see Hoppe 1972; Salvigsen 1978, 1981; Landvik et al. 1987). These data indicate that the formation of the two skua-mounds on the shores started shortly after the emergence of these shores from the sea.

\section{Cumulative long-distance pollen}

Cumulative long-distance values (Figs. 6 and 7, extreme right) can be helpful for detecting time gaps in the record of the two diagrams. This will be explained below. Pollen influx values of a certain type are defined as the number of grains deposited per year per $\mathrm{cm}^{2}$. The total long-distance influx values for the two sites are expected to be similar, because (1) the diagrams represent roughly the same period of time, (2) the distance between the sites (c. $75 \mathrm{~km}$ ) is small compared to the distance between the sites and the source areas of the long-distance pollen (c. $1000 \mathrm{~km}$ ), (3) local conditions that could influence pollen deposition are similar.

The apparent average influx of total long-distance pollen for the studied period, i.e. the average quantity that is effectively accumulated per $\mathrm{cm}^{2}$ per year, was calculated by dividing the cumulative long-distance value at the level of the radiocarbon date by the (calibrated) age of the radiocarbon date. Results are c. 2.7 long-distance 
transported grains $/ \mathrm{cm}^{2} /$ year for Meodden and c. 0.75 long-distance transported grains $/ \mathrm{cm}^{2} /$ year for Agardhdalen. However, this apparent average influx might be lower than the actual average influx, because of the occurrence of time gaps in the records due to (1) outwash of pollen after deposition, (2) erosion of peat layers, (3) periods of stagnation of peat growth.

Comparison of the two sites. - The large difference between the apparent average influx values for the two skua-mounds indicates that the time gap is considerably larger in Agardhdalen than in Meodden. Differences in the outwash of pollen or in the erosion of peat layers cannot explain the discrepancy in the time gaps, for the following reasons:

- Outwash of pollen was probably less important in Agardhdalen than in Meodden, since the lithology indicates that the Meodden skuamound is more water-permeable.

- The lithology indicates that erosion of peat layers was greater in the Meodden skua-mound.

It is therefore concluded that the time gap in the Agardhdalen skua-mound is mainly due to the stagnation of peat growth.

\section{Past climate}

The interpretation so far has given a few indications about the climate in the past. These are summarized and discussed below.

As stated earlier, skua-mounds can be termed small 'guanogenic bogs'. The existence of guanogenic bogs seems to depend on an Arctic climate. This climate must therefore have prevailed in Svalbard for at least 4500 calendar years.

The changes to a cooler climate which are indicated at two different levels in the Meodden section seem to be of a different order of importance. The climatic shift suggested in and at the base of zone 4 seems to be of major importance, since it is based both on biostratigraphy and on lithostratigraphy. On the other hand, the climatic change suggested at $8.5 \mathrm{~cm}$ from the top is based only on a change in specific-weight values and could therefore be of minor importance.

The type of data of the Agardhdalen section which pointed to a cooling of the climate is similar to the type of data used to support the occurrence of a major climatic shift at Meodden. The two events have not been dated and may not be synchronous. A possible date is the beginning of the Subatlantic c. 2400 B.P., when there was a general cooling in the northern hemisphere.

\section{Summary and conclusions}

Skua-mounds are common in Svalbard. They are rounded peaty hillocks, up to $10 \mathrm{~m}$ across and up to $70 \mathrm{~cm}$ high, which Arctic Skuas use for surveying their breeding territory. They are heavily manured and generally situated on coastal plains. Well-developed skua-mounds in Svalbard can be called small 'guanogenic bogs', because peat formation on them depends on manuring by birds and because the water-table in them is above the surrounding tundra. This type of bog can only exist in an arctic climate. Two skua-mounds were studied in detail: one from Meodden on Edgeøya and one from Agardhdalen on Spitsbergen. The peat layers, which are $40 \mathrm{~cm}$ and $34 \mathrm{~cm}$ thick, respectively, were studied for pollen and spores and were radiocarbon dated. Results which are similar for the two skua-mounds are:

- Peat formation started c. 4500 calendar years ago.

- A time gap in the records is assumed at the top of the sections.

- The biostratigraphy suggests fluctuating abundance of the dominant vascular plant species, which is interpreted in terms of fluctuating intensities of manuring by Arctic Skuas.

- The inferred fluctuations in manuring intensities suggest possible additional time gaps in the records of the upper zones.

- The biostratigraphy reflects a transition from a heavily to a moderately manured vegetation at a level about half-way up the sections, where a climatic shift towards cooler conditions is inferred.

Results which are different for the two skuamounds are:

- During the studied period grass was dominant on the Meodden skua-mound and mosses were dominant on the Agardhdalen skua-mound.

- Erosion of peat has progressed considerably further on the Meodden skua-mound.

- The difference in peat erosion is presumed to be related to differences in hydrology: the peat of the Meodden skua-mound is dry and unfrozen in summer, whereas in the Agardhdalen skua-mound it is wet and frozen and therefore less susceptible to erosion.

- Cumulative long-distance pollen values indicate 
that the time gap in the record is considerably larger in the Agardhdalen section.

- A second, minor climatic shift towards cooler or drier circumstances is inferred for Meodden, during a period later than the first climatic shift.

Acknowledgements. - I am grateful to Jacqueline F. N. van Leeuwen for her help at all stages, Dr. C. R. Janssen, Dr. B. Fredskild and Dr. J. de Korte for their comments, Ms. S. M. McNab for linguistic improvements, Paul Wartena and Aljos Farjon for preparation of the drawings and Dr. W. G. Mook for the radiocarbon dates.

\section{References}

De Korte, J. 1972: Birds, observed and collected by 'De Nederlandse Spitsbergen Expeditie' in West and East Spitsbergen, 1967 and 1968-69; second part. Beaufortia 19, 197-232.

Eurola, S. \& Hakala, A. V. K. 1977: The bird cliff vegetation of Svalbard. Aquilo Ser. Bot. 15, 1-18.

Fægri, K. \& Iversen, J. 1975: Textbook of pollen analysis (3rd edition). Munksgaard, Copenhagen. 295 pp.

Gore, A. J. P. 1983: Introduction. Pp. 1-34 in Gore, A. J. P. (cd.): Ecosystems of the world $4 A$ - Mires: swamp, bog, fen and moor - General studies. Elsevier Sci. Publ. Co., Amsterdam-Oxford-New York. $440 \mathrm{pp}$.

Hoppe, G. 1972: Ice sheets around the Norwegian Sea during the Würm glaciation. Meddelanden från Naturgeografiska Institutionen vid Stockholms Universitet A 50.

Landvik, J. Y., Mangerud, J. \& Salvigsen, O. 1987: The Late Weichselian and Holocene shoreline displacement on the west-central coast of Svalbard. Polar Research 5 n.s., 29-44.

Mook, W. G., de Jong, A. F. M. \& Geertsema, H. 1979: Archaeological implications of natural carbon-14 variations. Palaeohistoria $X X I, 9-18$.
Moore, P. D. \& Bellamy, D. J. 1974: Peatlands. Elek Science, London. 221 pp.

Pearson, G. W., Pilcher, J. R., Baillie, M. G. L., Corbet, D. M. \& Qua, F. 1986: High-Precision ${ }^{14} \mathrm{C}$ Measurement of Irish Oak to Show the Natural ${ }^{14} \mathrm{C}$ Variations from AD $1840-5210$ BC. Radiocarbon 28(2B), 911-934.

Rønning, O. 1979: Svalbards flora. Norsk Polarinstitutt Polarhåndbok 1. $128 \mathrm{pp}$.

Salvigsen, O. 1977: An observation of palsa-like forms in Nordaustlandet, Svalbard. Norsk Polarinstitutt Arbok 1976, 364-367.

Salvigsen, O. 1978: Holocene emergence and finds of pumice, whalebones, and driftwood at Svartknausflya, Nordaustlandet. Norsk Polarinstitutt Årbok 1977, 217-228.

Salvigsen, O. 1981: Radiocarbon dated raised beaches in Kong Karls Land, Svalbard, and their consequences for the glacial history of the Barents Sea area. Geogr. Ann. 63 A (3-4), 283-291

Stockmarr, J. 1971: Tablets with spores in absolute pollen analysis. Pollen et Spores 13(4), 615-621.

Stuiver, M. \& Becker, B. 1986: High-Precision Decadal Calibration of the Radiocarbon Time Scale, AD 1950-2500 BC. Radiocarbon 28(2B), 863-910.

Van der Knaap, W. O. 1985: Human influence on natural Arctic vegetation in the seventeenth century and climatic change since A.D. 1600 in north-west Spitsbergen: a paleobotanical study. Arctic and Alpine Research 17, 371-387.

Van der Knaap, W. O. 1987: Five short pollen diagrams of soils from Jan Mayen, Norway: a testimony to a dynamic landscapc. Polar Research 5 n.s., 193-206.

Van der Knaap, W. O. 1988: Age and stability of bird-manured vegetation on Spitsbergen. Acta Botanica Neerlandica 37(2) (in print).

Van Leeuwen, J. F. N. \& Van der Knaap, W. O. 1986: Vogelleven op Brøggerhalvøya, Spitsbergen. Circumpolar Journal 2(1), 36-45.

Verbeek-Reuvers, A. A. M. L. 1977: The Northwest European Pollen Flora 9. Saxifragaceae. Rev. Palaeobot. Palynol. 24(NEPF), 31-58. 
